\title{
Cost prediction model based on system dynamics in water resource project
}

\author{
Hirijanto $^{1, *}$, I Wayan Mundra ${ }^{1}$, and Addy Utomo ${ }^{1}$ \\ ${ }^{1}$ Department of Civil Engineering, National Institute of Technology Malang, Indonesia
}

\begin{abstract}
Project's cost is one of important components in project achievement. Because of the uniqueness of construction projects, cost estimation always differs from project to project. The rate of cost components always change over time make difficult to forecast the cost for the upcoming project. The cost component consists of many influencing variables where there is interrelationship each other affecting to the total project cost. This paper objective is to develop a cost prediction model to assist the project planners in cost estimation for future projects. System dynamic is one of the appropriate methods to analyse system behaviour with interrelationship referring to the historic data, so it is able to predict the future project. Developing the model, primary and secondary data are collected from previous studies, interview with the government planner and survey in Malang Regency. The model simulation is Brick work unit with its components. Data from last thirteen years are used to verify and validate the developed model by causal loop diagram as a basic method in system dynamic. The finding showed that the model is closed to real condition through the validation mechanism. The developed system is useful in decision making of budget planning based on work quantity.

Keywords: Prediction model, Project cost, System dynamics.
\end{abstract}

\section{Introduction}

Construction project cost is one of the constraints dealing with the cost planning, so the planner must be very rigorous. It involves the unit price of work. In Indonesia, each division in Public Work Department establishes their own pricing policy based on the past data and adjustment of calculation results from other divisions. A simple calculation is made to accommodate value alteration over time. This traditional approach has caused the funds holder unable to forecast project cost over the long terms. This problem is also experienced by the Water Resources Division in Malang Regency, so it takes the right method to predict the cost [12].

Some previous research has tried to predict the project cost with various models. Neural network and fuzzy logic have been used to predict future cost estimation in project. Some statistical model-based approaches are also commonly used for prediction of project cost $[19,20,21]$. Neural network has already proved to be more reliable in predicting, but this method requires a lot of historical data to arrange a pattern closed to reality. Meanwhile, fuzzy logic is more suitable for cases of decision making based on qualitative analysis. The statistical approach using scientific and objective forecast generally apply constant assumption, so it is not appropriate to accommodate the dynamic changes in project cost estimation.

System dynamic is a method of problem solving due to causal dependence of the variables in system. System dynamic is used to understand how something change over time, provides an explanation of the process in system and predicts the outcome from various scenarios, so it can be used to support decision making and forecast tool. In accordance with the weakness of previous method and the advantages of system dynamic, this method is one of the appropriate solutions to be used in forecasting the project cost.

Based on the existing problem, the purpose of this paper is to develop a project cost prediction model based on its components with system dynamics approach. This model is a part of the final goal in developing a database information technology for project cost planning system.

\subsection{Project Cost Estimation}

A construction project requires some resources (labor, material and machine), money and method to support its implementation. This resource needs expenses, so it must be properly planned [2].

* Corresponding author: janto.hiri22@gmail.com 
According to Lantang et.al [8] project cost estimation is the calculation of each cost requirement to pay for resources used, including other costs associated with the project implementation. The basis of budgeting system design can use a current schedule in project implementation to predict future events by observing existing data. There are some contributing factors in project cost prediction, that are: manpower productivity, material availability, machine/equipment availability, weather, type of contract, problem of quality, ethic, controlling system, and managerial skill.

Estimation is more to an art than a technique; therefore there is no precise estimation for all kinds of work. Some researches mention the factors influencing project cost estimation are complexity of project, data completeness, team work, contract, project duration and market demand. From the analysis of previous result showed that the dominant factors were complexity of design, quality of design specification, project's topography condition, payment system, experiences in handling projects, the applied contract in work, funding/financing system, total productivity, output quality based on planning, pricing fluctuation of resources and stability of market. Almost all these factors influence the output or performance of a project. $[1,3,15,16]$.

Meanwhile, according to Sugiyarto [13] estimation is an effort of measuring or value estimation through calculation analysis based on experiences. Generally, the estimation procedure are based on historical data or experiences. Expert judgment or analogy from similar project are usually used to decide the estimation with a minimum existing data [11].

Istimawan in Sugiyarto [13] said that estimation in construction project is an application of engineering concept based on the procurement document, field condition and resources from contractor. Project cost estimation is predicted through primary factors such as condition of the project, contract, construction schedule, applied technology for the project, labour productivity and cost estimation model. All factors are used to calculate the unit price of work according to index value or coefficient of resources analysis as the productivity that is different according to the skill and habitual level of each resource [5].

The basic steps in project cost estimation at design stage are:

a. Source of information, previous or past time experiences.

b. Earlier data from previous projects added with accurate reports.

c. Reports or applied standards.

d. Economic condition, both in micro or macro scale.

e. Social condition

f. Environment condition

The type of cost estimation can be described based on its purpose, the amount of expenses every meter square, according to entire building components, based on quantity and computation implemented on unit price of work and estimation based on quantity volume work computation analysis [13].
Generally, project cost consists of direct and indirect cost. A direct cost is type of expenses that is affecting to project achievement directly such as time, quality and resources usage during the implementation of project. Direct cost are cost components from unit price of work which is composed of labour wage, material cost, and machine cost [4]. The definition for indirect cost in this research is a type of expense that must be paid for supporting components in project implementation, which is divided into two categories; overhead and benefit according to regulation. Overhead is cost for operational and expenses for central office which is not taken from procurement cost, such as managerial cost, accounting cost, training and auditing cost, license, registration, advertisement cost, promotion and public relation cost, etc.

Taxes is also included into indirect cost. The amount of general cost and benefit will be determined by several considerations such as interest rate, inflation rate, overhead from central office, construction field, and also investment risk [4]. Basically, indirect cost will be determined not more than $15 \%$ according to previous working experiences [7].

\subsection{The Unit Price Analysis of Work (AHSP)}

The unit price analysis of work (AHSP) is the cost calculation from the components of worker, material and machine/equipment to determine the unit price of particular work. According to Figure 1, the analysis is constructed referring to direct and indirect cost [4].

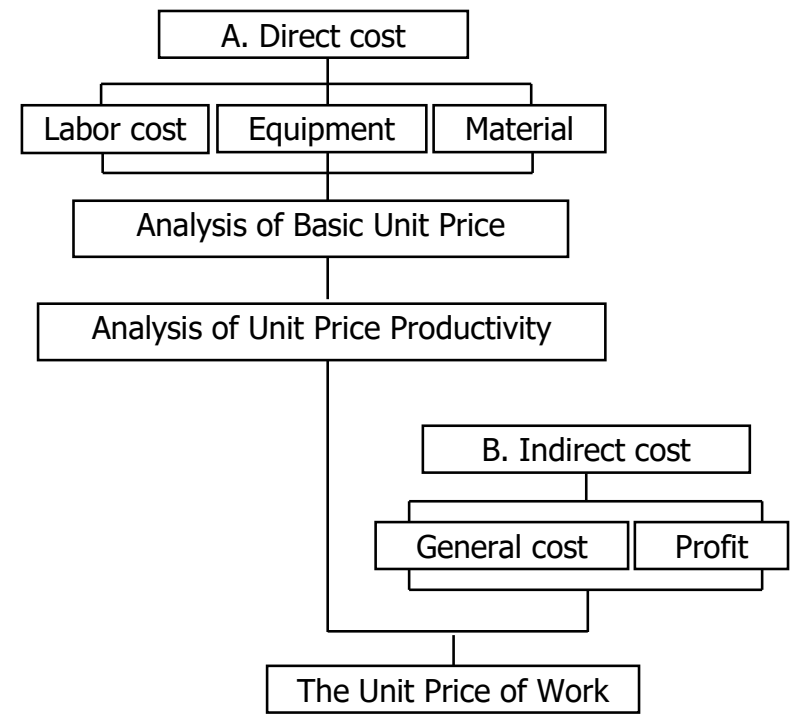

Fig. 1. Structure of The Unit Price Analysis of Work

From direct cost perspective, resources can be detached into several components such as labour, building material and equipment component. The unit price analysis of work is derived from the basic unit price of these resources as shown in Figure 2, Figure 3 and Figure 4. 


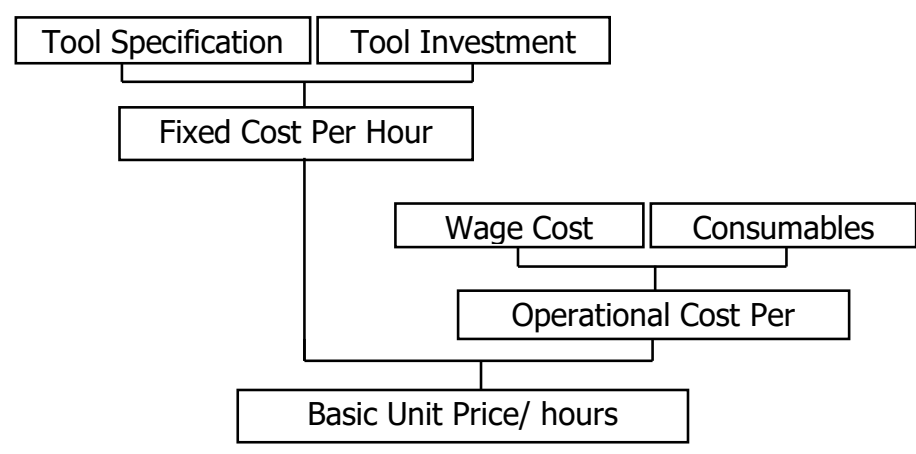

Fig. 2. Structure of The Basic Unit Price Analysis of Equipment

The basic unit price of equipment is depending on fixed cost from investment and operational cost when its own machine or rental cost. The basic consideration to establish the unit price of material is information from the Central Bureau of Statistic and world bank, market price data, survey, inflation rate, economic growth and rupiah exchange rate. The unit price of worker is calculated based on their productivity. The influencing factors for basic unit price are number of workers with their skill level, minimum wage (UMR) in each region and gross domestic product (GDP) [4].

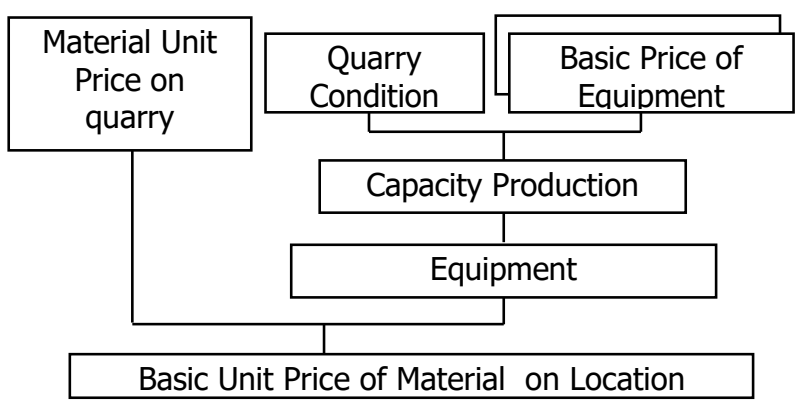

Fig. 3. Structure of The Basic Unit Price Analysis of Material

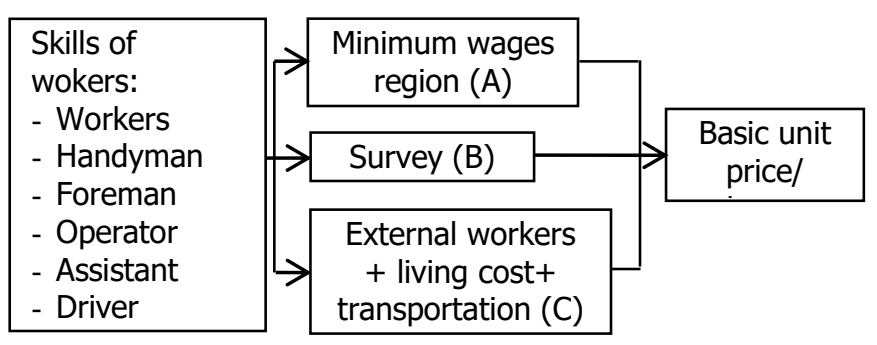

Fig. 4. Structure of The Basic Unit Price Analysis of Wages

\section{Method}

Research methodology in this paper follows the pattern of problem solving in system dynamic analysis, started with variable identification stage, creating the causal loop diagram using causatic diagram and stock flow diagram, verification and system validation, and the last step is model simulation, as shown in Figure 5 [9, 14].

\subsection{Data Collection}

The data in this research comes from several previous studies, updated data from interview with four fundholder of Water Resources Division of Public Work Department in Malang Regency, material supplier which spread in four areas in Malang Regency and field interviews with project manager from three water resources project in Malang Regency to complete sufficiency data.

The primary data of wage and material price list from the local government was collected from 2005-2017 (13 years).

According to the work scope in water resources project, there are many types and breakdown activities. General activity is one such example, i.e.: earthwork, brick work, concrete work, pile work, dewatering work, water gate and hydromechanics. Brick work unit is used as an example of a model simulation in this paper. Based on the SNI standard, for $1 \mathrm{~m}^{2}$ brick work needs workers (labour, mason, head mason and foreman), materials (brick, Portland cement and sand) and equipment (manual mixer). Portland cement, mason and manual mixer are chosen as a case in model simulation. Coefficient index of material and worker for brick work with 1Pc: $3 \mathrm{~S}$ specification is Portland cement (0.05), mason (0.01) and manual mixer (0.01).

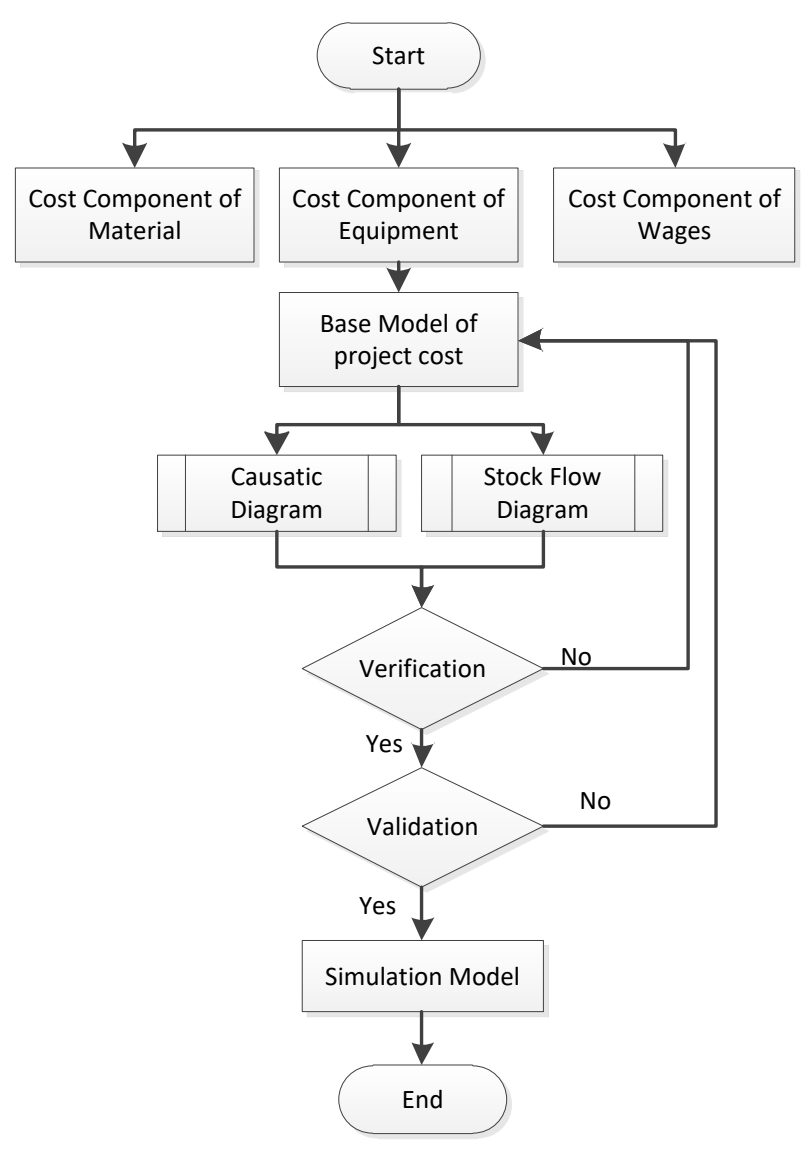

Fig. 5. The Scheme of Cost Model Prediction 


\subsection{Causal Loop Diagram}

\subsubsection{Components of System}

Based on previous studies, interviews and surveys, it can be concluded that project cost components for budget planning are derived from several sub systems i.e.:
5. Sub-System of Work Direct Cost which consists of :
a) Work Unit Price
b) Work volume
c) Value added tax (VAT) of work

6. Sub system of indirect cost which consists of:
a) Benefit
b) General fees

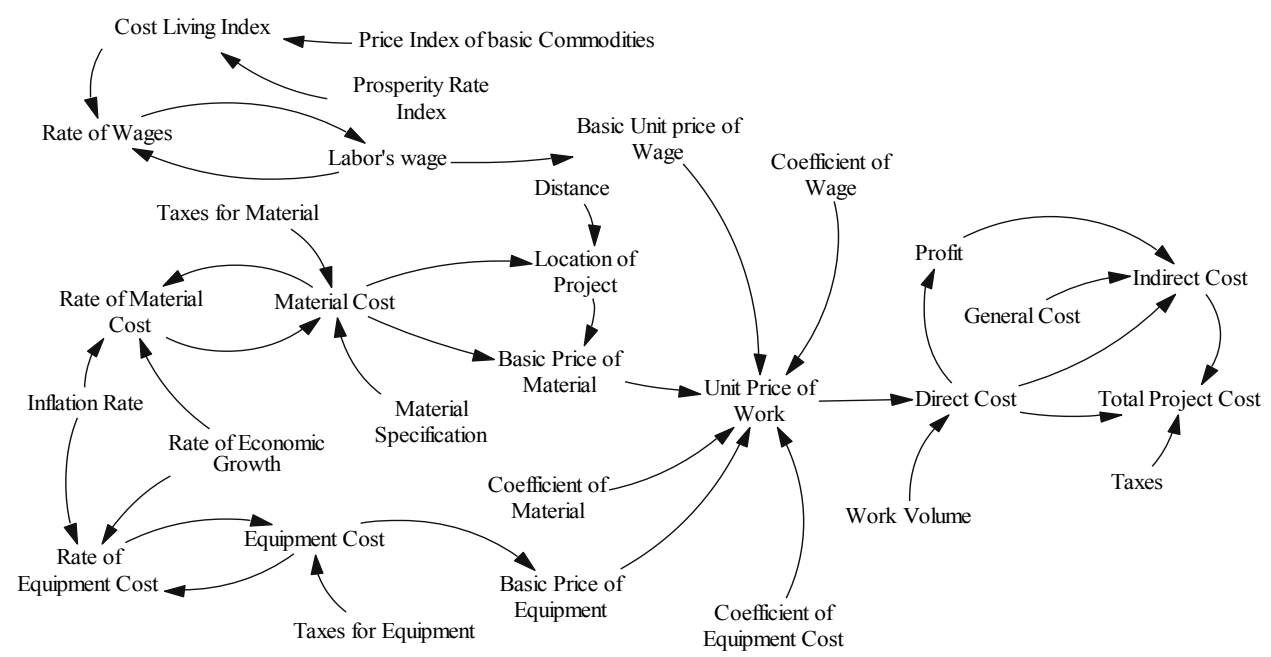

Fig. 6. Causatic Diagram.

1. Sub system of material basic unit price consists of components:

a) The rate of material price

b) Inflation and inflation rate

c) Economic growth and economic growth rate

d) Value added tax (VAT) and income tax of material

e) Material specification

f) Location and the distance of material purchases

2. Sub system of equipment basic unit price consists of components:

a) The rate of equipment price

b) Inflation and inflation rate

c) Economic growth and economic growth rate

d) VAT and PPH of equipment.

3. Sub system of wage basic unit price consists of components:

a) The rate of worker's wage

b) Staple price index

c) Cost of living index

d) Prosperity index and income levels per capita Population

4. Sub System of Work Basic Unit Price that consists of components:

a) Basic Unit Price Material

b) Basic Unit Price Equipment

c) Basic Unit Price Wage

d) Material Coefficient.

e) Equipment Coefficient.

f) Wage Coefficient. c) Value added aax (VAT) of work

\subsubsection{Causal Loop Diagram}

According to the component identification in system, causatic diagram can be arranged with the consideration based on previous studies and interviews analysis to decide the interrelationship between components. Based on the interrelationship in causatic diagram, then the stock flow diagram is created by adding mathematical equation into the developed system with the same approach. Ventana simulation (vensim) software is used to help in system development to be more simple and faster, as shown in Figure 6 and Figure 7 [6, 18].

\section{Results}

The causatic diagram indicated that there were interrelationship between components and also showed the behaviour description of the project cost system. For the simulation process, the stock flow diagram is used to show the effect of scenario procedure and its changes because the stock flow diagram is using quantitative analysis from mathematical expression. Through these two approaches, the basic model has already developed and the system can be used to forecast the future project cost.

\subsection{Verification and Validation}




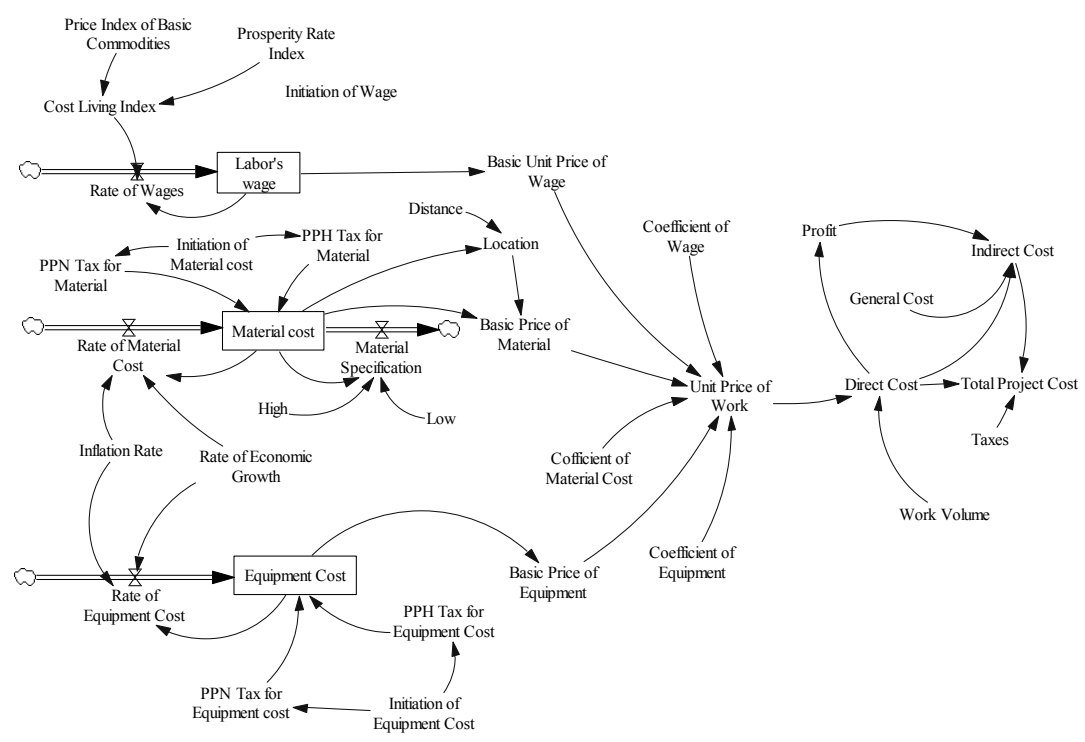

Fig. 7. Stock Flow Diagram.

The next phase is verification and system validation of the basic model. Verification is the stage of ensuring that the developed model is running well and shows the final output according to the expectation (there is no mistake in the mathematical expression which is inputted into the system). If the model has been able to show the estimation values in stock flow diagram, it means that the model is verified, as shown in Figure 8.

When the basic model is still found a mistake (unverified), the model must be checked first, but if it has already verified, then the next step is a model validation. However, validation is a process to ensure the developed system that closed to the real condition. The data base of price list from material and wage that has been collected for the last of thirteen years (2005-2017) was used to validate the model in this study. The accuracy of validation result is obtained by using two techniques; mean comparisons (E1) and comparisons of amplitude deviation \% error variance (E2) between the output values from the model and the existing database. The output of validation process from the basic model for material price is $\mathrm{E} 1=0.978 \%<5 \%$ and the amplitude deviation value of E2 $=4.80 \%<30 \%$. Meanwhile for validation result of the equipment price is
$\mathrm{E} 1=0.51 \%<5 \%$ and the amplitude deviation value of $\mathrm{E} 2=1.05 \%<30 \%$. The final calculation for validation output of worker's wage is E1 $=0.89 \%<5 \%$ and the amplitude deviation value of $\mathrm{E} 2=2.30 \%<30 \%$. These results show that the model has already validated because the value of E1 and E2 is smaller than the provisions limit. The result of the basic model as shown in Figure 8.

\subsection{Simulation Model}

After the basic model has been verified and validated and describes the condition of the system in real terms, then the scenario process is applied to the basic model to see the behaviour whether there is a conditional changing in system. There are two types of simulation scenario in system dynamic; parameter scenario and structure scenario. For this study, the structure scenario is applied.

The first scenario in this paper is applied the basic condition without change for thirty years, so that the cost prediction over the seventeen years will be obtained. The prediction of wage, material cost, equipment cost, and total project cost as shown in Figure 9. 


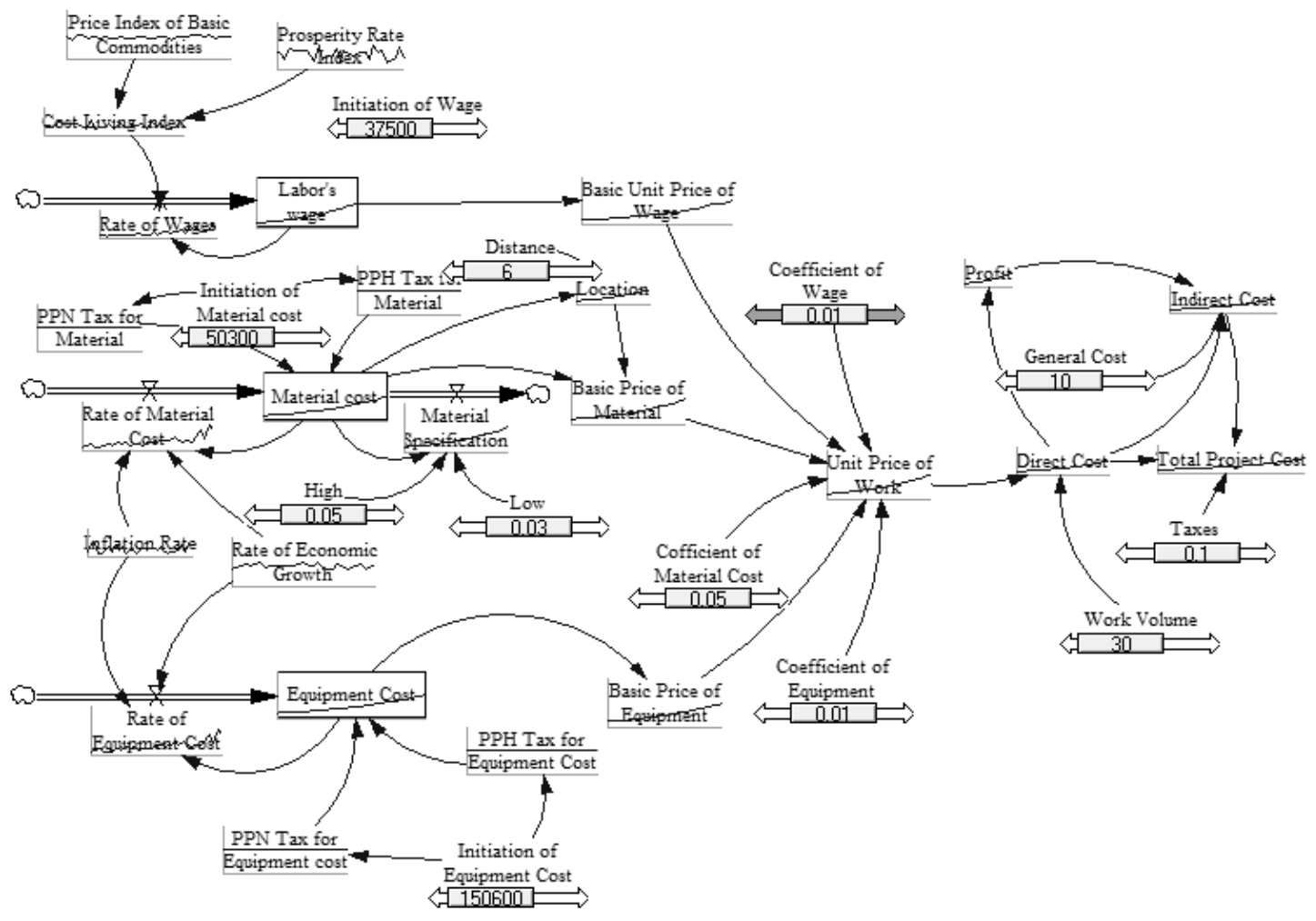

Fig. 8. Model verification
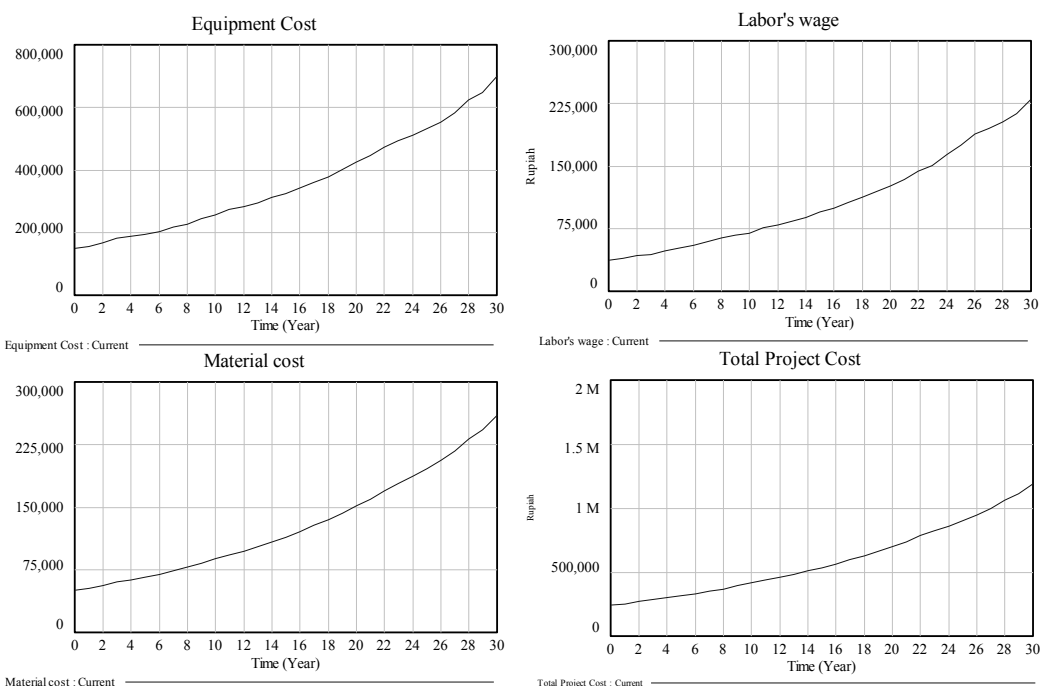

Fig. 9. Cost Prediction for First Scenario. 


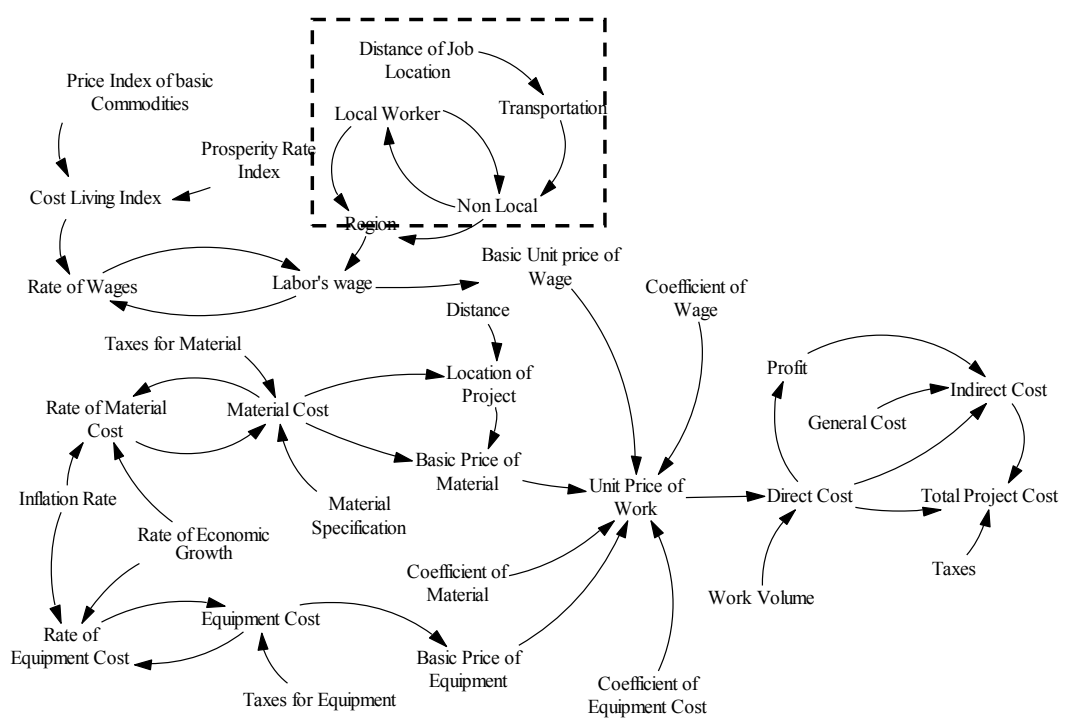

Fig. 10. Causatic Diagram For Second Scenario

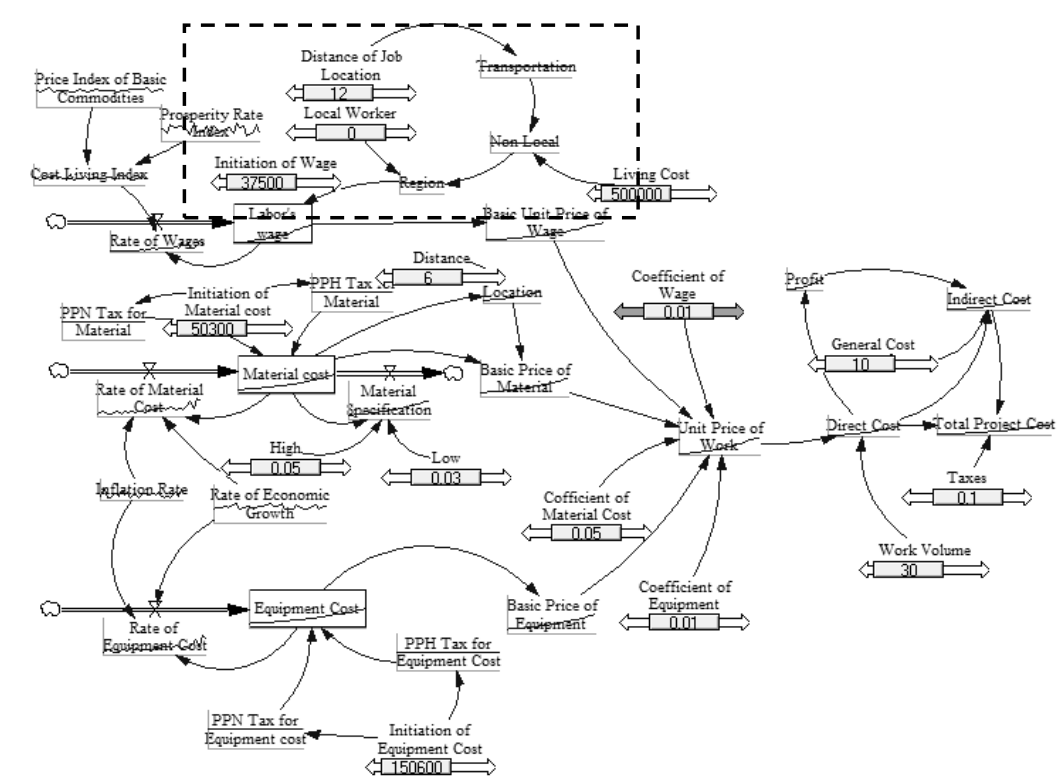

Fig. 11. Stock Flow Diagram for Second Scenario

The second scenario is accommodated when the local worker has limited number so it must be hiring from other region as non-local worker. Based on this condition, several considerations should be made and affect to the additional components in the system such as transportation, living cost and distance from the project location. The causal loop diagram should be modified by adding the components according to the scenario requirement. The changes in causatic diagram and stock flow diagram are marked within the box (Figure 10 and Figure 11). This scenario is an example of structure scenario because there are changes in the system variables.

According to both scenarios, a comparative of cost prediction can be compiled (Figure 12 and Figure 13). 


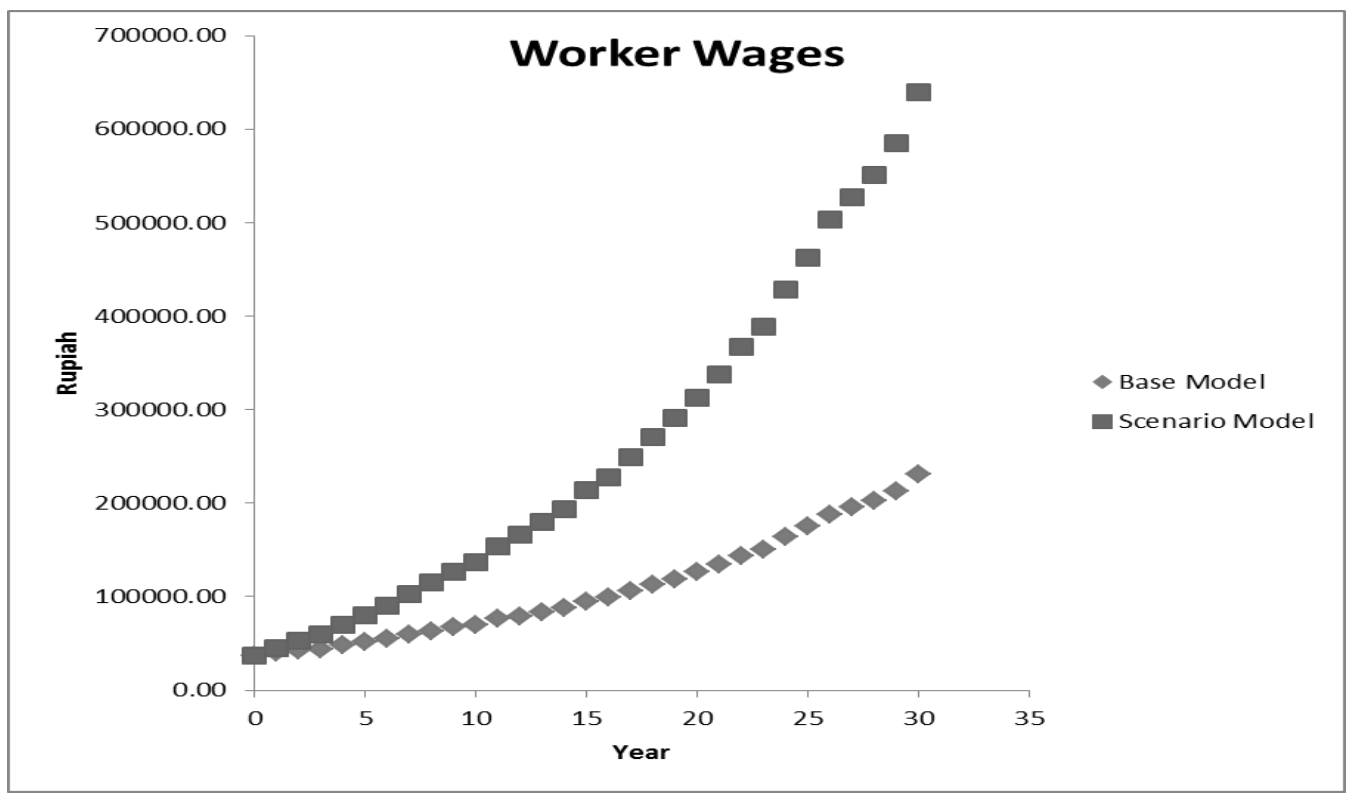

Fig. 12. The Comparison of Worker's Wage Value

Figure 12 shows the comparison between base model (uses local worker) and the scenario model (uses both local or non-local workers). It can be observed that the conducted scenario due to application of non-local workers has given different prediction value for worker wage for about $50.90 \%$ at the end of its $30^{\text {th }}$ year. The use of non-local worker causes the worker's wage more expensive than local workers.

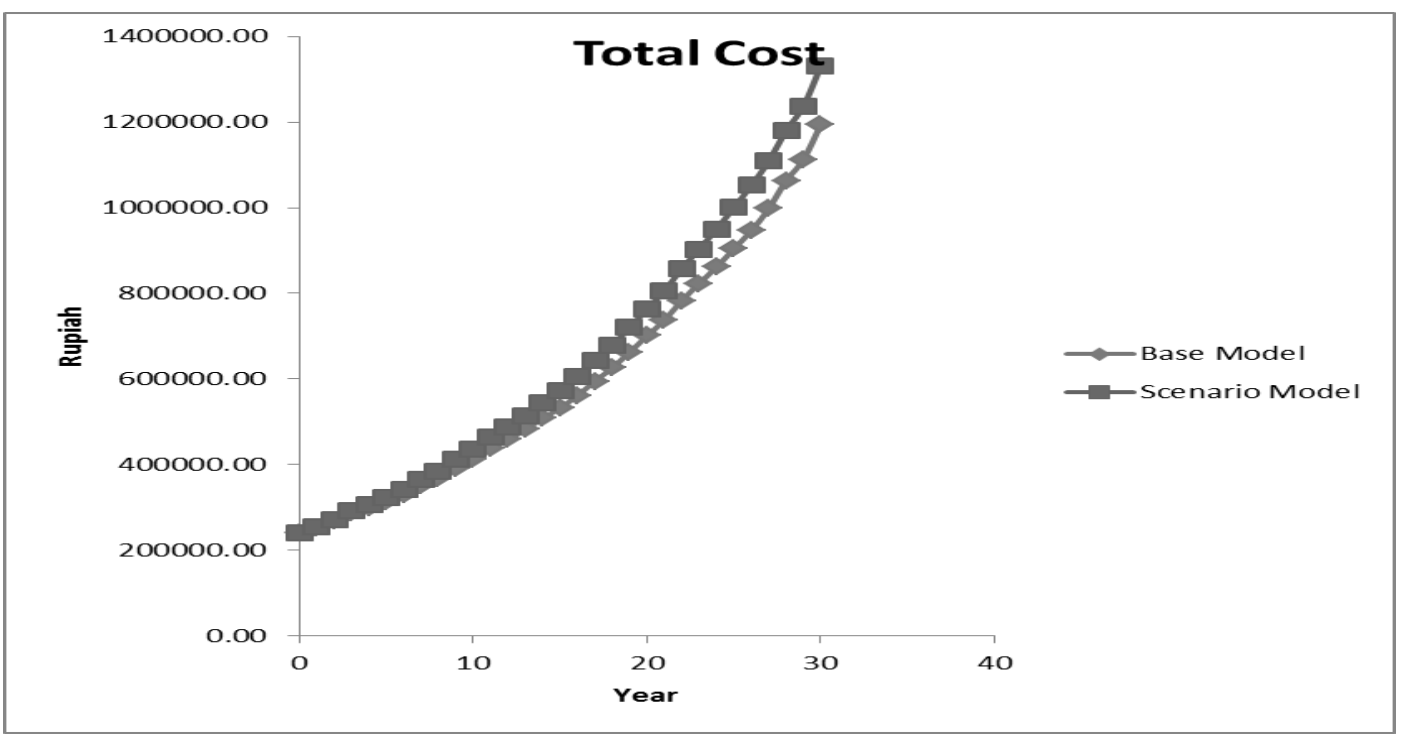

Fig. 13. The Comparison of Project Total Cost

The differences of prediction in worker's wage is also influencing the calculation of the total project cost prediction for about $6.54 \%$ at the end of its $30^{\text {th }}$ year. Although the influence of local and non-local workers uses suggestion a large number of differences in predictive models, it has a little effect on change in the total project cost because there are many other variables that also affect to the total prediction cost of project.

\section{Conclusions and Suggestion}

Using a system dynamic approach, a prediction model has been developed to support the planner in a budget plan based on work quantity, especially for water resources division in construction project. The developed model shows that the behaviour of the system when there are any changes over the time for each component or in whole system.

The verification and validation of model have shown that the developed model is appropriate and closed to the real conditions. The result of base model can be used as alternative solution to predict the longterm project cost based on identified cost components.

The experimental simulation with scenario implementations shows the influence degree of each cost components as well as the whole system making. It is 
easier for the planner to classify the significant factor leading to increase the project cost. The expectation goal of this approach is a long-term prediction of project cost for budget plan with their cause and effect.

However, this model has some limitations such as an enormous entry system requirement when all activities in project are analyzed. The developed cost system becomes very complex and it makes difficult to evaluate when any errors occurred. Therefore, the future researches need to combine the analysis with a database information system application to support the project cost prediction model to be easier and friendly for planner.

\section{References}

1. A. Akintoye, Construction Management and Economic 18, 77-89 (2000)

2. D. Arumningsih, Jurnal Teknik Sipil dan Arsitektur Universitas Tunas Pembangunan Surakarta 12 (16), (2012)

3. R. F. Aziz, Alexandria Engineering Journal 51, 5166 (2013)

4. Balitbang-PU, Pedoman Bahan Konstruksi Bangunan dan Rekayasa Sipil (Kementrian Pekerjaan Umum, Jakarta, 2012)

5. D. T. Herwansyah, (http://www.gunadarma.ac.id) (Mei 2017) (2008)

6. Hirijanto, S. Hidayat, Konferensi Nasional Teknik Sipil 10, 351-358, (Program Studi Teknik Sipil Fakultas Teknik Universitas Atma Jaya Yogyakarta, Yogyakarta 2016)

7. A. Idrus, M. F. Nuruddin, M. A. Rohman, Expert System with Applications 38, 1501-1508 (2011)

8. F. N. Lantang, G. Y. Malingkas, B. F. Sompie, Jurnal Sipil Statik 2 (2), 73-80 (2014)

9. U. Rahayu, Simulasi Dinamika Sistem Ketersediaan Ubi Kayu (Institut Pertanian Bogor, Bogor, 2006)

10. Ripkianto, L. A. Winanda, Seminar Nasional Teknik Sipil VII (Institut Teknologi Sepuluh Nopember, Surabaya, 2012)

11. S. Sequeira, E. Lopes, Conference on ENTERprise Infomation Systems, pp. 537-544, (Elseiver Procedia Science, Castelo Branco, 2015)

12. I. Soeharto, Manajemen Proyek Dari Konseptual Sampai Operasional (Erlangga, Indonesia, 1995)

13. Sugiyarto, (http://sipil.ft.uns.ac.id) (2017) (2013)

14. E. Suryani, JUTI 9 (2), (2011)

15. T-C. Toh, C. Ting, K-N Ali, G-U. Aliagha, O. Munir, International Conference On Asia Pasific Business Innovation and Technology Management, pp. 360-367 (Elseiver Procedia Social and Behavioral, 2012)
16. W-C. Wang, S-H. Wang, Y-K. Tsui, C-H. Hsu, Expert System With Applications, 5358-5366, (2012)

17. L. A. Winanda, Seminar nasional Teknik Sipil V (Institut Teknologi Sepuluh Nopember, Surabaya, 2013)

18. L. A. Winanda, Hirijanto, Munasih, PROKONS Jurnal Teknik Sipil, 80-84 (2015)

19. V. Suveka, T. S. Priya, IJSER 8 (5), 160-164 (2017)

20. V. Suveka, T. S. Priya, IRJET 3 (11), 757-760 (2016)

21. F. Shutian, Z. Tianyi, Z. Ying, Engineering Computations 34 (7), 2396-2408 (2017) 